\title{
A Study of Cooperative Learning in Higher College English Teaching
}

\author{
Jing Chen \\ Department of Foreign Languages, Tangshan Vocational \& Technical College, China \\ Ying Wang \\ College of Foreign Languages, Hebei United University, China
}

\begin{abstract}
Cooperative learning has been used not only as both an instructional method, but also as a learning tool at various subjects and different level of educations. The aim of this study is through comparing the traditional lecture-based method and the cooperative learning method in the higher college English teaching, in order to explore how higher college students perceive the means of cooperative learning in terms of English oral performance, English learning attitudes or motivation, social skills, and the lowering of anxiety in speaking English.
\end{abstract}

Index Terms - cooperative learning, teacher-centered approach, college English learning

Learning English has continued to become ever more important for college students. English proficiency not only benefits them in their academic studies, career hunting and professional promotion, but also enables them to successfully pursue trade or work opportunities. Hence, as English teachers, preparing the students of today to become successful individuals of tomorrow, we must ensure our English teaching effective, useful and ensure the students not only acquire process skills but also develop positive attitudes. While for this, cooperative learning has done a good job.

\section{The Traditional LeCture-BASED Method}

Traditional lecture-based instruction places emphasis on the lecturer and deep learning through memorizing. Traditional learning refers to the teacher giving out information; students listen and speak only when called on by the teacher. This learning method has mastered our English teaching for a long time. In a classic study on traditional teaching, numerous researchers found that for the most part, what takes place in the classroom requires the attention of all the students. Teachers tend to stay in front of the classroom more than 85 percent of the time when teaching the whole class, but they change their location on an average once every 30 seconds. They further found that student participation is restricted by the environment or physical setting itself in ways that neither the teacher nor students are aware. Formal seating patterns tend to reduce student-to-student eye contact and student interaction and to increase student control and student passivity. The traditional structure may give each student five to ten minutes a day to speak about academic topics or respond to questions from the teacher. Traditional teaching gives emphasis on parts and isolated knowledge. Studies verify that when teachers depend upon "whole class instruction" they themselves talk more than two-thirds of the time, and more than $70 \%$ of their "teacher talk" is spent disciplining, lecturing, giving instructions, and asking questions. Students work together mainly to make clear how assignments are to be done. They try to find each other's information, but have no idea to teach what they know to their group members. Helping and sharing is minimized.

Some students don't put themselves into the task preparation, they just stay alone at the corner and wait for the efforts of their more diligent group members. The conscientious members feel exploited and do less. The result is that the more hard-working and the diligent students always better while the not active students will become more far way from the class. As for the teaching of English in colleges, judging from the loud voice of criticizing English instruction and the appeal for decreasing English credit-hours from six to four, in colleges, we may recognize that most college students are probably losing interest and motivation in learning the language. Seriously speaking, some of them are disgusted and, therefore, are rejecting the subject of English. Studies have shown that teacher-centered classrooms tend to pour standardized curriculum into the heads of nonstandardized students. It also awards just the students who have the right answers. Traditional teaching shows low expectations for students of different cultures. It is high time that all the professionals in this field to seriously think over the issue and figure out possible solutions since the expected mainstream with a good command of English has become extremely important to our country in striving to join the world.

\section{THE COOPERATIVE LEARNING}

\section{A. Theoretical Foundations of Cooperative Learning}


The theoretical foundation of cooperative learning stems from two broad perspectives. The first holds the developmental perspective, derived in part from the theory of Vygotsky and the second holds the motivational perspective, related to the work of Lewin and Deutsch. Vygotsky was a pivotal figure in the history of cooperative learning with his approaches to language acquisition and cognitive development. He suggests, as a result of collaborative activities increasing information processing, that motivation to learn is enhanced with language as the key mode through which the students organize their thinking and regulate their actions. Therefore, from a Vygotskian perspective, a major role of schooling is to create social contexts for mastery of and conscious awareness in the use of these cultural tools. (Vygotsky, 1962) When students engage in activities and dialogue with others, they gradually develop the dialogue expressing into their inner speech, which direct their own behaviors and thinks. And also the inner speech they carry on become the foundation of a social dialogue with others and is a major mode of learning, planning, and self-development. Vygotsky's research (1962) suggested that school helps students draw generalizations and "construct" meaning from their own experiences, knowledge, and strategies. The motivational perspectives of Lewin and Deutsch on cooperative learning proceed from a different starting point than Vygotsky's. Motivationlists are concerned with goal structures that create a situation in which the only way group members can obtain their own personal goals is by group success. Cooperative goal structures create a situation in which the only way group members can attain their own personal goals is if the group is successful. (Slavin, 1987) Giving students a reasonable sense of control over their experiences increases their motivation to engage in learning tasks.(DeCharms, 1976) Hence, either the developmental or motivational perspective of cooperative learning produces students making knowledge their own through intense interaction with others.

The source of motivation in cooperative learning is the supportive nature of the students' relationships with their peers in small groups and the important role each person plays within cooperative learning groups. The competitive atmosphere of the traditional classroom reduces the effects on motivation in many students. By contrast, cooperative small groups foster interest in the tasks by including shared goals, mutual encouragement and assistance, and the opportunity to contribute to the group's progress regardless of one's academic status in the class. The features of cooperative learning groups positively manifest socialization as a powerful motivating factor.

Studies of the benefits of oral interaction found that elaboration strategies were used more frequently by individuals in groups than by those in individualistic situations. According to Judy, these strategies involve reorganizing and clarifying material that the student does or does not understand. As a result, elaboration influences the learning of both the student offering the help and the student receiving the help. Johnson et al.(1990) address in their book Circles of Learning that there are nine points of differences between traditional learning groups and cooperative learning groups. These differences are summarized as follows: (Johnson et al., 1990)

\begin{tabular}{|l|l|}
\hline \multicolumn{2}{|l|}{ Comparison between Cooperative Learning and Traditional Learning } \\
\hline Cooperative Learning & Traditional Learning \\
\hline Positive interdependence & No interdependence \\
\hline Individual accountability & No individual accountability \\
\hline Heterogeneous membership & Homogeneous membership \\
\hline Shared leadership & One appointed leader \\
\hline Responsible for each other & Responsible only for self \\
\hline Task and maintenance emphasized & Only task emphasized \\
\hline Social skills directly taught & Social skills assumed and ignored \\
\hline Teachers observes and intervenes & Teacher ignores group functioning \\
\hline Group process occurs & No group processing \\
\hline
\end{tabular}

\section{B. The Definition of the Cooperative Learning}

Johnson and Holubec defined Cooperative Learning (CL) as "the instructional use of small groups so that students can work together to maximize their own and each other's learning". Explicitly, cooperative learning is an approach to teaching and learning in which classrooms are organized so that students work together with positive interdependence and individual accountability in small cooperative groups. When properly organized, students in cooperative groups make sure that everyone in the group has mastered the concepts being taught. (Slavin, 1997)

Cooperative learning believes that learning is most effective when students are actively concerned with sharing ideas and working cooperatively to complete teaching tasks. According to Slavin,(1997) cooperative learning has entered the mainstream of educational practice for a number of reasons: firstly, the overwhelming amount of research showing the use of cooperative learning to improve student achievement and other such outcomes as inter-group relations, acceptance of handicapped classmates, and increase of esteem. Secondly, the growing of realization that students must learn to think, solve problems, integrate their knowledge, and apply their skills--cooperative learning is an excellent means for doing this. Thirdly, cooperative learning can help make diversity in heterogeneous classes a source, rather than a problem. As schools are moving away from homogeneous ability grouping with its negative effects on student achievement toward more heterogeneous grouping, cooperative learning is growing in importance. Fourthly, cooperative learning has been found to positively influence the social relations with students of different ethnic

\footnotetext{
${ }^{1}$ Johnson, D. W., Johnson, R. T., and Holubec, E. J. (1990). Circles of learning: Cooperation in the classroom (p.16), Edina, MN: Interaction.
} 
backgrounds and mainstreamed special education students and their classmates. (Slavin, 1997) Therefore, cooperative learning not only improves students' emotional well-being, self-esteem, and coping skills, but also their attitude toward school work. (Patrick 1994; Patterson 1994)Students engaged in cooperative learning experiences have been able to identify an increase in their own knowledge and self-esteem, trust of peers, problem-solving and communication skills, (Elliott, Busse, \& Shapiro, 1999), and technology proficiency. (McGrath, 1998)

In cooperative learning, individuals can achieve promotive interaction by helping each other, exchanging resources, challenging each other's conclusions, providing feedback, and encouraging and striving for mutual benefits. (Zakaria and Iksan, 2007) Students work together to accomplish the shared goals. Students are given two responsibilities: to maximize their own learning and to maximize the learning of all other group members. (Deutsch, 1949a) Students perceive that they can reach their learning goals if, and only if, the other students in the learning groups also reach their goals. (Deutsch, 1949a) Hence, students search for results that are beneficial to all those with whom they are cooperatively connected.

\section{Features of Cooperative Learning}

The cooperative efforts in certain conditions may be expected to be more productive than competitive and individualistic efforts. Five major essentials are used to demonstrate cooperative learning and to make cooperative learning more successful. These essentials are: positive interdependence, face-to-face communication, individual responsibility, social skills, and group processing.

1. Positive interdependence

For many years, schools, teachers, and parents have promoted an "I, me, my," mentality in the students. Students have always been told in school to, "do your own work," "keep your eyes on your own paper," "sharing answers is considered cheating," and the list can go on and on. Cooperative learning, however, seeks to change that by restructuring the reasons for students to work together. The first element, positive interdependence, seeks to do just that.

According to Johnson \& Johnson, (1990) the success of one learner is dependent on the success of the other learners. During cooperative learning activities, the accomplishment of the group goal should rely on all group members working together and coordinating their actions. Positive interdependence is the insight that you are joined with others in a way so that you cannot succeed unless your group members do (and vice versa); that is, their work benefits you and your work payback them. It promotes a situation in which students work together in small groups to make the most of the learning of all members, sharing their resources, providing joint support, and celebrating their joint success. Teachers must provide a precise learning task and a group goal so that students know they "sink or swim together" (Johnson \& Johnson, 1990, p. 28). Often, learners in the cooperative learning context have dual responsibilities: (a) They have to learn the assigned materials, and (b) they also have to concern other group members' learning. Positive interdependence is the essence of cooperative learning - it is achieved when students think in terms of "we" versus "me". Students should not feel successful until each member has attained both the group learning goal and his or her individual learning goal(s). (Johnson et al., 1990) This may require that students tutor one another and check on one another's progress. In addition, positive interdependence also has great influence on students' motivation, learning attitudes and productivity. When members of a group see their efforts as necessary for the group's success, they will increase their efforts. (Harkins \& Petty, 1982)

2. Face-to-face communication

Once a teacher establishes positive interdependence, they need to maximize the opportunity for students to promote each other's success by helping, assisting, supporting, encouraging, and praising each other's efforts to learn. (Johnson \& Johnson, 1992) Students should interact directly with one another while they are working. They may communicate verbally and/or nonverbally. Interaction should take place among students, rather than between students and materials or students and machines.(Johnson et al., 1990) When students are asked to work independently on a set of problems and then meet in groups to discuss the answers, they are not really engaging in cooperative learning, but rather in individualistic learning - with talking. For cooperative learning to be effective, the members of the group have to be in very close physical proximity, face to face. In a cooperative learning setting, the teacher is prepared to step aside and offer the learner a more meaningful role. Students in a group sit in circle and interact with each other. As a matter of fact, cooperative groups can help increase opportunities for members to produce comprehend language, promote active learning, and also give quick feedback to their peers. Finally, while positive interdependence creates the circumstances for working together, it is the real face-to-face communication, in which students work together and help each other's success, that the personal relationships are shaped are important for developing pluralistic values.

3. Individual responsibility

Individual responsibility exists when the performance of each individual student is assessed and the results are given back to the group and the individual.(Johnson \& Johnson, 1992) All students should be held individually responsible for learning the material and contributing to the group. Insisting on individual responsibility discourages "coasting" or "hitchhiking," in which one or a few of the students do the bulk of the work and the others take a free ride. Individual evaluations are essential in determining whether each student has mastered the material. Teachers can test each student individually, or they can randomly select a student from each group to respond to questions or demonstrate or explain the material to the class. According to Olsen \& Kagan, (1992) it is important that the group knows who needs more assistance, support, and encouragement in completing the assignment. It is also important that group members know 
that they cannot "hitch-hike" on the work of others. Each individual is accountable for his or her own learning and is also accountable to the group. This means that grading takes into account individual grades and group grades. (Olsen $\&$ Kagan, 1992)Teachers should judge the total effort that each member is contributing. And the judgment can be done by giving an individual test to each student or accidentally asking students to present their group's work.

Individual responsibility exists when each student is given equal responsibility for his or her fair share to the teamwork. It stresses the idea that the accomplishment of a group relies on the coordination of all members' efforts. Each team member feels in charge of their own and their members' learning, and then makes an active contribution to the group. As reported by Johnson, and Holubec(1994), another aspect of individual accountability is that each team member must master the learning materials. Group members have to make certain that learning takes place by checking for understanding, quizzing, and tutoring of one another.(Johnson, and Holubec,1994) According to Johnson et al. (1991a), individual accountability can be promoted by (a) keeping the size of the group small, (b) giving an individual test to each student, (c) calling on students in the class randomly and asking students to present the work of the group to the entire class, (d) observing how members of each group interact with other members, (e) assigning one member of each group to ask other group members to explain new material to the rest of the group (i.e., checker), and (f) requiring that each student teaches what he/she learned to a fellow group member or to someone else from another group. (Johnson et al., 1991a)

4. Social Skills

According to Johnson and Johnson (1990), contributing to the success of a cooperative effort requires interpersonal and social skills.(Johnson and Johnson, 1990) Developing students' social interaction is an important career-related liberal arts skill valued by employers and by faculty members in a variety of disciplines. Social skills should be taught and reinforced for high quality cooperation; and students should be encouraged to use them if cooperative groups are to be productive. Cooperative skills are social skills commonly used in group activities. Social behaviors are the basis of human communication. It is often necessary to explicitly teach the language and behavior needed to work together in English. Cooperative learning allows individual students the opportunity to work with others on a shared task, in pursuit of a common goal. (Cooper, 1990) Cooperative learning helps students develop different types of human relations skills such as active listening, empathy, consensus building, leadership, constructive conflict management, and resolution-skills that are relevant and transferable to the sorts of social situations they may encounter in their future careers. (Cooper, 1990)

However, even within positive research regarding cooperative learning there are opponents. Most opponents of cooperative learning do not fully understand its necessary components. They charge that during group work one student might end up doing everything while the others get a free ride. Moreover, telling the socially unskilled individual student of a group to cooperate with others does not assure that they will be able to do so effectively. In order to execute lessons in true cooperative learning style, there must be two key elements present: firstly, a common goal or purpose set for the team members to achieve, and secondly, individual responsibility. So, teachers must conduct the students the social skills of high quality cooperation and encourage them to practice. And at the same time, other social skills such as decision-making, leadership, communication, conflict-solving, etc. have to be cultivated just as decisively and accurately as academic skills. In addition, teachers must offer opportunities for each group members to know about and help each other, appreciate, accept and support each other, communicate actively and resolve discrepancies constructively, without which, students will merely take part in the group work and will not harvest the precious benefits that true cooperative learning has proven to bring.

5. Group Processing

According to Johnson and Johnson (1990), group processing may be defined as reflecting on a group session to describe what member actions are helpful or obstructive, and make decisions about what actions should continue or change. Students must also be given the time and procedures for analyzing how well their learning groups are functioning and the extent to which students are employing their social skills in helping all group members to achieve and to maintain effective working relationships within the group. It involves reflecting on a group session to describe what actions of the members were effective and ineffective and deciding upon which acts to continue, which to modify, and which to discard.( Johnson and Johnson,1990) According to Johnson, D.W. \& Johnson R.T.(1994) such processing (a) enables learning groups to focus on group maintenance, (b) facilitates the learning of social skills, (c) ensures that members receive feedback on their participation, and (d) reminds students to practice collaborative skills consistently. (Johnson \& Johnson, 1994)At the end of an activity or unit, the group reflects on how it has performed by reviewing the skills that it practiced, what it did well, and what it needs to do on next time. Teachers may provide a handout to track use of the skills. Besides, teachers should also give opportunities for the class to assess group progress. Group processing enables groups to focus on a good working relationship, facilitates the learning of cooperative skills, and ensures that members receive feedback. (Johnson \& Johnson, 1994)

\section{ThE EFFECTS OF IMPLEMENTING COOPERATIVE LEARNING}

\section{A. It Gives Students a Good Learning Performance.}

Students instructed by means of cooperative learning performed significantly better in speaking. Due to the abundant opportunities provided for the highly interactive settings with the classmates in CL method, most of the students 
achieved significantly better competence in listening and speaking. The participants' significant gains in English speaking and listening could be attributed to the highly interactive learning tasks, the continual peer discussion, peer correction, and the comfortable learning atmosphere during the class. The frequent interactions among the participants resulted in large numbers of student talks during the class. It is likely that the participants' speaking ability improved, as well as their listening, reading, and writing abilities. As a result, such a student-centered approach helps to enhance the students' oral communicative competence. The gains of the participants' communicative competence correspond to McGrath's (1998) suggestion that by continually stimulating language input and output, cooperative learning instruction provides English learners with natural settings in which they can derive and express meaning frequently from an academic setting. (McGrath's, 1998)

\section{B. English Learning Attitude/Motivation}

Students had higher learning satisfaction through the cooperative learning instruction than the control group had with the traditional approach. Small group discussions in a cooperative learning setting can provide learners with more opportunities to speak than is the case with teacher-centered instruction. That is, the participants receiving the cooperative learning instruction tended to become more motivated to study harder and get involved in the group discussion and learning activities.

The participants' responses in the interview showed that a team working together in order to complete the task can arouse the participants' desire for attaining successful use of language. This finding clearly demonstrates the significant efficiency of cooperative learning in supporting the participants' learning attitudes/motivations. The students felt they benefited more in learning attitudes/motivation than in their speech performance.

\section{It Enhances Students'Social Skills.}

Cooperative learning helped to improve their social relationships, both in cooperation with group members and contribution to others. In order to achieve the best effect from cooperative learning, it is essential for the instructor to organize heterogeneous groups in the cooperative class. When the subjects have problems, they will ask each other for help. In addition, the high-achievers will encourage their group members to work harder to get the reward for their group. They count on their teammates instead of learning from the instructor alone. With the assistance of high-, medium-, and low-achievers, students will have better performance than ever before. In addition, the requirements for teamwork also help to generate a sense of group belongings, and positive interdependence in class. Students in the group have to contribute to their group members. Teammates are required to work together and fulfill their tasks in order to get good scores. Under these circumstances, students' social esteem and self-esteem are raised, and a more harmonious atmosphere is cultivated in the cooperative classroom.

\section{It Reduces Students'Anxiety in English Oral Proficiency}

Cooperative learning may provide a more effective and less anxiety-provoking opportunity for students to gain enhanced fluency and confidence in their English-speaking skills which, in turn, could benefit them in other college classes that require public speaking, as well as help them in their professional careers later after college. Also, cooperative goal constructions create a situation in which the only way group members can attain their own personal goals is if the group is successful. In either the developmental or motivational perspective, students acquire knowledge on their own through intense interaction with others. And the students try their best to get the results which are beneficial to all those with whom they are cooperatively linked. They discuss assignments together, understand the meaning together, and encourage to find the answer each other. By doing these, students feel comfortable enough to participate in the activities and do their best in order to achieve common goals. So, peer cooperation and encouragement can reduce students' anxiety in speaking English.

\section{Pedagogical Implications}

First of all, it was found that cooperative learning worked well in fostering the students' communicative competence in oral English communication. Cooperative learning can benefit both high- and low-achievers. However, it is impossible to adopt a specific method to solve all the problems that happen in the classroom settings and to suit for every individual. In future studies, it is highly recommended for teachers to plan and adapt their teaching methods and procedures to a particular context. With careful and thoughtful planning and preparation, cooperative learning could be effective and useful in college speaking classrooms.

Secondly, since individual accountability has been found to be an important factor in cooperative learning, instructors must explain to students that all teammates have to make a good contribution in order to complete the tasks. Generally speaking, most teachers feel deeply frustrated about students' poor academic performance and low motivation in English learning. So, cooperative learning techniques could offer those teachers an alternative to motivate their students to expend greater effort to improve their academic performance. 


\section{REFERENCES}

[1] Adams, D. M. \& Hamm, M. E.(1990).Cooperative learning: Critical thinking and collaboration across curriculum. Springfield, Illinois: Charles Thomas Publisher.

[2] Cooper, J. (1990). Cooperative learning and college teaching: Tips from the trenches. In M. Weimer (Ed.), The teaching professor (pp. 114-139). University Park, PA: The Pennsylvania State University.

[3] DeCharms, R. (1976). Enhancing motivation: Chang in the classroom. Irvington, NY: Halsted-Wiley.

[4] Deutsch, M. (1949a). A theory of cooperation and competition. Human Relations, 2, 129-152.

[5] Elliott, S. M., Busse,R. T. \& Shapiro, E. S.(1999). Intervention techniques for academic performance problems. In C. R.Reynolds \& T. B. Gutkin (Eds.), The Handbook of School Psychology (pp. 664-685). New York: John Wiley.

[6] Harkins, S. \& Petty, R. (1982). The effects of task difficulty and task uniqueness on social loafing. Journal of Personality and Social Psychology 43, 1214-1229.

[7] Johnson, D.W. \& Johnson, R. T. (1990). Cooperative learning and achievement. In S. Sharan (Ed.), Cooperative Learning: Theory and Research (pp. 23-37). NY: Praeger Publishers.

[8] Johnson, D. W., Johnson, R. T., \& Holubec, E. J. (1990). Circles of learning: Cooperation in the classroom. (3rded.). Edina, MN: Interaction.

[9] Johnson,D. W. \& Johnson, R.T. (1992).Implementing cooperative learning. Contemporary Education, 63(3), 173-180.

[10] Johnson, D. W., Johnson, R. T. \& Holubec, E. J. (1994). Cooperative Learning in the Classroom. Alexandria, VA: Association for Supervision and Curriculum Development.

[11] Johnson, D. W., Johnson, R. T. \& Smith, K.A. (1991a). Cooperative learning: Increasing college faculty instructional productivity. College Teaching, 55(2), 51-57.

[12] McGrath, B. (1998). Partners in learning: Twelve ways technology changes the teacher-student relationship. T.H.E Journal, 25(9), 58-61.

[13] Oslen, R. \& Kagan, S. (1992). About cooperative learning. In C. Kessler (Ed.), Cooperative language learning: A teacher's resource book (pp.1-30). Englewood Cliffs, NJ: Prentice Hall.

[14] Patrick, J. (1994). Direct teaching of collaborative skills in a cooperative learning environment. Teaching and Change, 1(2), 170-181.

[15] Patterson, V.E. (1994). Introducing cooperative learning at princess Elizabeth elementary school. Education Canada, 34(2), 36-41.

[16] Slavin, R.E. (1997). Cooperative learning: Theory, research, and practice. Massachusetts: Allyn and Bacon.

[17] Slavin, R.E. (1987). Cooperative learning and the cooperative school. Educational Leadership, 45(3), 7-13.

[18] Vygotsky, L. (1962). Thought and language. Cambridge, MA: MIT Press.

[19] Zakaria, Effandi. \& Iksan, Zanaton. (2007). Promoting Cooperative Learning in Science and Mathematics Education: A Malaysian Perspective. Eurasia Journal of Mathematics, Science \& Technology Education, 2007, 3(1), 35-39.

Jing Chen was born in Tangshan, China in 1978. She received her M. D in English language and literature from Hebei University, China in 2010.

She is currently an instructor in Tangshan Vocational and Technical College, Tangshan, China. Her research interests include business English and linguistics.

Ying Wang was born in Tangshan, China in 1978. She received her M. D in linguistics from Dongbei University of Finance and Economics, China in 2009.

She is currently an instructor in Hebei United University, Tangshan, China. Her research interests include business English and linguistics. 